\title{
Development and Validation of a Stability- Indicating RP-HPLC Method for the Simultaneous Estimation of Bictegravir, Emtricitabine, and Tenofovir Alafenamide Fumarate
}

\author{
Biktegravir, Emtrisitabin ve Tenofovir Alafenamid Fumaratın Eşzamanlı \\ Kestirimi için Stabilite Göstergeli RP-HPLC Yönteminin Geliştirilmesi ve \\ Validasyonu
}

\author{
(D) Tanuja ATTALURI*, (D) Ganapaty SERU1, (D) Satya Narayana Murthy VARANASI² \\ 1Department of Pharmaceutical Analysis and Quality Assurance, Gitam Institute of Pharmacy, GITAM (Deemed to be University), Rushikonda, \\ Visakhapatnam, India \\ 2Dr. Reddy's Laboratories, Hyderabad, India
}

\begin{abstract}
Objectives: The focal intent of the current research work is to develop and validate a novel and reliable stability-indicating reverse-phase high performance liquid chromatographic method for the simultaneous estimation of a few anti-retrovirals, i.e., bictegravir, emtricitabine, and tenofovir alafenamide fumarate (AF).

Materials and Methods: The novel method employs inertsil octyldecylsilyl $\mathrm{C}_{18}(4.6 \times 250 \mathrm{~mm}, 5 \mathrm{~mm})$ using $0.2 \%$ triethylamine buffer and methanol in a ratio of $40: 60 \%(\mathrm{v} / \mathrm{v})$ as the mobile phase to attain optimal elution. The detection wavelength was $260 \mathrm{~nm}$ with a $1.2 \mathrm{~mL} / \mathrm{min}$ flow rate and a 20 $\mu \mathrm{L}$ injection volume.

Results: The linearity ranges for bictegravir, emtricitabine and tenofovir AF were $25-125 \mu \mathrm{g} / \mathrm{mL}, 100-500 \mu \mathrm{g} / \mathrm{mL}$, and $12.5-62.5 \mu \mathrm{g} / \mathrm{mL}$, respectively. The retention times for bictegravir, emtricitabine, and tenofovir AF were found to be $5.998 \mathrm{~min}, 2.805 \mathrm{~min}$, and 4.537, min respectively. The percent recoveries of bictegravir, emtricitabine, and tenofovir AF were within the range of $98-102 \% \mathrm{w} / \mathrm{w}$.

Conclusion: The novel method was successfully validated as per International Conference on Harmonization guidelines. In forced degradation studies, emtricitabine was found to be sensitive to thermal conditions; bictegravir and tenofovir AF, to oxidative conditions. The developed method is economical and reliable for routine analysis concerning all validated parameters.
\end{abstract}

Key words: Bictegravir, emtricitabine, tenofovir AF, RP-HPLC, validation, forced degradation studies

öz

Amaç: Mevcut araştırma çalışmasının odak amacı, birkaç anti-retroviralin [biktegravir, emtrisitabin ve tenofovir alafenamid fumarat (AF)] eş zamanlı tahmini için yeni ve güvenilir bir stabilite gösteren ters fazlı yüksek performanslı sıvı kromatografik yöntemi geliştirmek ve doğrulamaktır.

Gereç ve Yöntemler: Yeni yöntem, optimal elüsyona ulaşmak için mobil faz olarak \%0,2 trietilamin tamponu ve \%40:60 (h/h) oranında metanol kullanan inertsil octyldesilsilil $\mathrm{C}_{18}{ }^{\prime} \mathrm{i}(4,6 \times 250 \mathrm{~mm}, 5 \mathrm{~mm})$ kullanmaktadır. Deteksiyon dalga boyu $260 \mathrm{~nm}$, akış hızı 1,2 mL/dk ve enjeksiyon hacmi 20 $\mu \mathrm{L}$ idi.

Bulgular: Biktegravir, emtrisitabin ve tenofovir AF'nin doğrusallık ranjı sırasıyla 25-125 $\mu \mathrm{g} / \mathrm{mL}, 100-500 \mu \mathrm{gg} / \mathrm{mL}$ ve $12.5-62.5 \mu \mathrm{g} / \mathrm{mL}$ idi. Biktegravir, emtrisitabin ve tenofovir AF'nin retansiyon zamanları sırasıyla 5,998 dk, 2,805 dk ve 4,537 idi. Biktegravir, emtrisitabin ve tenofovir AF'nin yüzde gerikazanımları \%98-102 a/a aralığında idi.

Sonuç: Yeni yöntem, Uluslararası Uyumlaştırma Konferansı yönergelerine göre başarıyla doğrulanmıştır. Zorla bozunma çalışmalarında, emtrisitabin termal koșullara biktegravir ve tenofovir AF ise, oksidatif koşullara duyarlı olduğu bulunmuştur. Geliştirilen yöntem, tüm valide edilmiş parametrelerle ilgili rutin analizler için ekonomik ve güvenilirdir.

Anahtar kelimeler: Biktegravir, emtrisitabin, tenofovir AF, RP-HPLC, validasyon, zorla bozunma çalışmaları

*Correspondence: attaluriswathi@gmail.com, Phone: 9014299789, ORCID-ID: orcid.org/0000-0001-7627-2625

Received: 26.04.2020, Accepted: 08.09.2020

๑Turk J Pharm Sci, Published by Galenos Publishing House. 


\section{INTRODUCTION}

Human immunodeficiency virus (HIV) is a fatal viral infection that targets and alters the immune system, increasing the risk and impact of other infections and diseases. If left untreated, the infection might progress to an advanced disease stage called acquired immunodeficiency syndrome (AIDS). With the use of multiple specialized anti-retroviral medications that are commercially available, the state of HIV/AIDS infection can be controlled, de-escalated, and treated. Among numerous antiretroviral formulations and combinations available, bictegravir is an oral tablet that contains three anti-retroviral drugs [bictegravir + emtricitabine + tenofovir alafenamide fumarate (AF)] under the brand name "BIKTARVY". Bictegravir belongs to the class of HIV-1 integrase strand transfer inhibitors (INSTIs); emtricitabine and tenofovir alafenamide, to the class of HIV-1 nucleoside analog reverse transcriptase inhibitors. Hence "BIKTARVY" can be considered as the sole regimen for HIV-1 (type 1) infected patients. ${ }^{1-3}$ The INSTIs comprise two nucleoside reverse transcriptase inhibitors and recommended components during the initial stages of anti-retroviral therapy. Bictegravir is an effective INSTI with a high in vitro barrier that shows strong resistance toward the clinically relevant drug-drug interactions and possesses specific activity against HIV-1 and HIV-2. Bictegravir is metabolized by cytochrome P450 3A4 and a uridine diphosphate glucuronosyl transferase 1A1. It binds to the active site of HIV integrase and prevents HIV replication. Compared with other INSTIs, bictegravir possesses a high barrier to in vitro resistance and a lower potential to drug interactions among other readily available anti-retrovirals. ${ }^{4,5}$ Emtricitabine and tenofovir AF act on DNA synthesis via HIV reverse transcriptase, resulting in viral DNA chain termination and preventing the replication of HIV.., 7 The US Food and Drug Administration has approved "bictegravir" as a fixed-dose regimen (once daily) to treat HIV-1 infection. ${ }^{8,9}$ The chemical structures of the three active pharmaceutical ingredients are shown in Figure 1-3. The dosage regimen is as follows:

Bictegravir (50 mg) + emtricitabine (20 mg) + tenofovir AF (25 $\mathrm{mg}$.

According to the "Department of Health and Human Services", 10,11 the current combination regimen is intended to treat HIV-1 patients. Biktarvy can be administered with or without food and is not recommended with other anti-retrovirals. ${ }^{12} \mathrm{~A}$ literature survey was performed, and very few stability-indicating reverse-phase high performance liquid chromatographic (HPLC) isocratic elution methods to estimate the drugs of interest are reported.<smiles>C[C@H]1[C@@H]2CC[C@H]1N1C(=O)c3c(O)c(=O)c(C(=O)NCc4c(F)cc(F)cc4F)cn3CC1O2</smiles>

Figure 1. Bictegravir<smiles>Nc1nc(=O)n(C2CSC3OC2CS3)cc1F</smiles>

Figure 2. Emtricitabine<smiles>CC(C)OC(=O)[C@H](C)NP(=O)(COC(C)Cn1cnc2c(N)ncnc21)Oc1ccccc1</smiles>

Figure 3. Tenofovir alafenamide fumarate

However, the available methods for determination of bictegravir, emtricitabine, and tenofovir AF in pharmaceutical formulations are scanty and vary in establishing multiple experimental variables during the validation of the method; the current method developed was found to be more sensitive and reliable. The details are outlined in Table 1.

Therefore, in the present work we developed a novel, reliable, and efficient method for the quantification of the drugs of interest. The stability of the drug indicates its shelf-life and bio-availability, which affect the chemical, pharmacological, and toxicological characteristics of the drug moieties; hence, stability studies were performed according to the International Conference on Harmonization ( $\mathrm{ICH}$ ) guidelines, and the results are reported.

\section{MATERIALS AND METHODS}

\section{Experiment}

\section{Collection of drugs}

Bictegravir of purity $99 \% \mathrm{w} / \mathrm{w}$, emtricitabine of purity $99 \% \mathrm{w} / \mathrm{w}$, and tenofovir AF of purity $99 \% \mathrm{w} / \mathrm{w}$ were procured from Hetero Labs, Hyderabad.

\section{Chemicals and reagents}

HPLC grade methanol (Rankem), Milli-Q grade water for HPLC (Merck), and HPLC grade triethylamine (Fine Chem Industries Research Laboratory) were used.

\section{Apparatus}

The HPLC WATERS system (2695 separation module 7 auto sampler) used in this method was equipped with a photodiode array (PDA) detector. Empower chromatography software (EMPOWER-2) was used for liquid chromatogram peak integration. Empower-2 software was used in data acquisition and processing. 
Table 1. Comparison with similar existing methods

\begin{tabular}{|c|c|c|c|c|c|}
\hline $\begin{array}{l}\text { Kokkirala and } \\
\text { Suryakala }{ }^{13}\end{array}$ & $\begin{array}{l}\text { Sneha and Valli } \\
\text { Kumari }^{14}\end{array}$ & Sattar and Achanta ${ }^{15}$ & $\begin{array}{l}\text { Meenaksh and Shyam } \\
\text { Sunder }^{16}\end{array}$ & Current method & Remarks \\
\hline $\begin{array}{l}\text { Buffer and } \\
\text { acetonitrile in a } \\
\text { ratio of } 50: 50\end{array}$ & $\begin{array}{l}\text { Buffer and } \\
\text { acetonitrile in a } \\
\text { ratio of } 55: 45 \mathrm{v} / \mathrm{v}\end{array}$ & $\begin{array}{l}\text { Mobile phase ratio } \\
\text { was ( } 30: 70 \mathrm{v} / \mathrm{v} \text { ) } \\
\text { ortho-phosphoric } \\
\text { acid buffer (adjust } \\
\text { the } \mathrm{pH} 2.5 \text { with } \\
\mathrm{NaOH} \text { solution): } \\
\text { methanol }\end{array}$ & $\begin{array}{l}\text { Buffer phosphoric } \\
\text { dihydrogen phosphate } \\
\text { as mobile phase A and } \\
\text { methanol and water } \\
(70: 30) \text { as mobile phase B } \\
\text { of the gradient program }\end{array}$ & $\begin{array}{l}0.2 \% \text { triethylamine } \\
\text { buffer and } \\
\text { methanol in the } \\
\text { ratio of } 40: 60 \\
\% \mathrm{v} / \mathrm{v}\end{array}$ & $\begin{array}{l}\text { Less expensive solvents } \\
\text { were employed to obtain } \\
\text { substantial results }\end{array}$ \\
\hline $\begin{array}{l}\mathrm{C}_{18} \text { column } \\
(150 \mathrm{~mm} \times 4.6 \mathrm{~mm}, \\
5 \mu \mathrm{m})\end{array}$ & $\begin{array}{l}\text { Zodiac } C_{18} 150 \times 4.6 \\
\mathrm{~mm}, 5 \mu \mathrm{m}\end{array}$ & $\begin{array}{l}\text { Inspire } C_{18} \text { column } \\
(150 \times 4.6 \mathrm{~mm}) 5.0 \mu \mathrm{m}\end{array}$ & $\begin{array}{l}\text { Inertsil 30V C } \mathrm{C}_{18} \text { Column } \\
(250 \times 4.6 \mathrm{~mm}, 5 \mu \mathrm{m})\end{array}$ & $\begin{array}{l}\text { Octyldecylsilyl } C_{18} \\
(4.6 \times 250 \mathrm{~mm}, 5 \\
\mu \mathrm{m})\end{array}$ & $\begin{array}{l}\text { Good peak shape and } \\
\text { resolution acquired }\end{array}$ \\
\hline $272 \mathrm{~nm}$ & $272 \mathrm{~nm}$ & $272 \mathrm{~nm}$ & $265 \mathrm{~nm}$ & $260 \mathrm{~nm}$ & $\begin{array}{l}\text { Detection of eluted peaks } \\
\text { acquired at a shorter } \\
\text { wavelength }\end{array}$ \\
\hline
\end{tabular}

a-The inertsil octadecylsilica (ODS) $C_{18}(4.6 \times 250 \mathrm{~mm}, 5 \mu \mathrm{m})$ column was found to be ideal for analyzing the selected drugs. b-A rheodyne injector ( $20 \mu \mathrm{L}$ loop) was used to inject the samples.

C-A ultraviolet (UV)-visible spectrophotometer (LABINDIA UV $300^{\circ+}$ ) with UV Win software was used to establish the analytical wavelength.

d-Other instruments included an afcoset ER-200A electronic weighing balance, micropipettes, pipettes, burettes, micro-pore filtration assembly, ultra-sonic water bath for sonication of the mobile phase, and $\mathrm{pH}$ meter (Adwa-AD 1020).

\section{Optimized chromatographic conditions}

Once several trials had been conducted for optimization, the appropriate conditions were selected for the study, the details of which are as follows:

Instrument: HPLC (waters) with auto sampler

Detector: PDA detector

Temperature: Ambient

Column: ODS $\mathrm{C}_{18}(4.6 \times 250 \mathrm{~mm}, 5 \mu \mathrm{m})$

Mobile phase: $0.2 \%$ triethyl amine (TEA), buffer: Methanol (40:60 v/v)

Flow rate: $1.2 \mathrm{~mL} / \mathrm{min}$

Run time: 15 min

Wavelength: 260 nanometers $(\mathrm{nm})$

\section{Preparation of $0.2 \%$ TEA buffer solution}

TEA ( $2 \mathrm{~mL}$ ) was measured accurately by pipetting into $1000 \mathrm{~mL}$ HPLC grade water and dissolved. The $\mathrm{pH}$ was adjusted to 3.5 with dilute formic acid.

\section{Preparation of the mobile phase}

Four hundred milliliters (40\%) of the above-prepared buffer and $600 \mathrm{~mL}(60 \%)$ of methanol were measured accurately and mixed well.
Standard and sample preparation (emtricitabine, tenofovir $A F$, and bictegravir)

\section{Standard preparation}

Emtricitabine (100 mg), tenofovir AF (12.5 mg), and bictegravir (25 mg) working standards were weighed into a volumetric flask and added to $100 \mathrm{~mL}$ of diluent to makeup the volume. From the prepared stock solution, $3 \mathrm{~mL}$ was diluted to 10 $\mathrm{mL}$. The resulting solution contained each of $300 \mathrm{ppm}$ of emtricitabine, $37.5 \mathrm{ppm}$, of tenofovir $\mathrm{AF}$, and $75 \mathrm{ppm}$ of bictegravir.

\section{Sample preparation}

Ten tablets [prepared in-house by weighing the quantities as stated in the marketed formulation of emtricitabine $(200 \mathrm{mg})$, tenofovir AF (25 mg), and bictegravir (50 mg)] were weighed accurately, and quantities equal to emtricitabine $(100 \mathrm{mg})$, tenofovir AF (12.5 mg), and bictegravir (25 mg) samples were diluted to $100 \mathrm{~mL}$. Three milliliters of each stock solution was diluted to $10 \mathrm{~mL}$ containing $300 \mathrm{ppm}$ of emtricitabine, $37.5 \mathrm{ppm}$, of tenofovir $\mathrm{AF}$, and $75 \mathrm{ppm}$ of bictegravir.

\section{Procedure}

The \% assay was estimated from the obtained peak areas of standard and sample using the formula:

$$
\% \text { Assay }=\frac{A T}{A S} \times \frac{W S}{D S} \times \frac{D T}{W T} \times \frac{\text { Average weight }}{\text { Label Claim }} \times \frac{P}{100} \times 100
$$

Where;

AT: Average area counts of test (sample) preparation.

AS: Average area counts of standard preparation.

WS: Weight of working standard taken in $\mathrm{mg}$.

DS: Dilution of working standard in $\mathrm{mL}$.

DT: Dilution of test (sample) in $\mathrm{mL}$.

WT: Weight of test (sample) taken in $\mathrm{mg}$.

P: Percentage purity of working standard. 


\section{Method validation}

The analytical method validation for the developed method was implemented to ensure that the method meet the intended requirements as stated in the respective guidelines. ${ }^{17}$ The results obtained for the method validation can be considered to determine the reliability and consistency of the developed method. The proposed method was validated according to the $\mathrm{ICH}$ guidelines with respect to the following parameters. ${ }^{18-21}$

Calibration curves were obtained at concentrations of 25-125 $\mu \mathrm{g} / \mathrm{mL}$ for bictegravir, $100-500 \mu \mathrm{g} / \mathrm{mL}$ for Emtricitabine, and 12.5-62.5 $\mu \mathrm{g} / \mathrm{mL}$ for tenofovir AF.

\section{Linearity}

Linearity can be illustrated by examining different concentrations of active pharmaceutical ingredients. The linearity of a method can be evaluated from the calibration plots of bictegravir, emtricitabine, and tenofovir AF constructed from peak response vs. concentration, which approaches a straight line.

Emtricitabine (100 mg), tenofovir AF (12.5 mg), and bictegravir (25 mg) were diluted to $100 \mathrm{~mL}$. From this stock solution, 1-5 $\mathrm{mL}$ was pipetted into five different $10 \mathrm{~mL}$ volumetric flasks, and a series of aliquots was prepared and analyzed.

\section{Accuracy}

Accuracy was illustrated from the \% recovery of standard containing known concentrations of active pharmaceutical ingredients.

Emtricitabine (100 mg), tenofovir AF (12.5 mg), and bictegravir (25 mg) working standards were diluted to $100 \mathrm{~mL}$.

Three milliliters of the resulting stock solution was diluted to $10 \mathrm{~mL}$. This solution thus contained emtricitabine (300 ppm), tenofovir AF (37.5 ppm), and bictegravir (75 ppm). The standard solutions for accuracy determination, 50\%, 100\%, and $150 \%$, were prepared and injected, and the recovery values for emtricitabine, tenofovir AF, and bictegravir were calculated.

\section{Precision}

Precision was evaluated on the basis of the closeness between the obtained results.

Emtricitabine (100 mg), tenofovir AF (12.5 mg), and bictegravir (25 mg) working standards were diluted to $100 \mathrm{~mL}$. Three milliliters of this stock solution was diluted to $10 \mathrm{~mL}$.

\section{Specificity}

Specificity can be illustrated by ensuring that the peaks are free from interference.

It is determined by injecting a blank and a standard into the chromatographic system and corroborating that no interference exists.

\section{Detection limit $(D L)$ and quantification limit $(Q L)$}

$D L$ and $Q L$ values deal with the method's sensitivity. $D L$ is the analyte's lowest detectable concentration, while $Q \mathrm{~L}$ is the lowest quantifiable concentration.
$D L$

Emtricitabine (100 mg), tenofovir AF (12.5 mg), and bictegravir (25 mg) working standards were weighed and diluted separately to $100 \mathrm{~mL}$. From this stock solution, $3 \mathrm{~mL}$ was diluted to 10 $\mathrm{mL}$. From the above, $1 \mathrm{~mL}$ of each of the above stock solutions (emtricitabine, tenofovir AF, and bictegravir) was dispensed into different $10 \mathrm{~mL}$ volumetric flasks and diluted with diluent. Emtricitabine stock solution $(0.35 \mathrm{~mL})$, tenofovir $A F(1 \mathrm{~mL})$, and bictegravir stock $(1 \mathrm{~mL})$ solutions were further diluted to 10 $\mathrm{mL}$.

QL

Emtricitabine (100 mg), tenofovir AF (12.5 mg), and bictegravir (25 mg) working standards were diluted to $100 \mathrm{~mL}$. From the stock solution, $3 \mathrm{~mL}$ was diluted to $10 \mathrm{~mL}$. Further, emtricitabine (1 $\mathrm{mL})$, tenofovir AF stock $(1 \mathrm{~mL})$ solutions, and bictegravir stock solution ( $3 \mathrm{~mL}$ ) were diluted to $10 \mathrm{~mL}$. Further pipette emtricitabine stock (1.1 mL) solution, tenofovir AF (4.1 mL) and bictegravir stock solution $(3.9 \mathrm{~mL}$ ) were diluted to $10 \mathrm{~mL}$.

\section{Robustness}

Robustness can be illustrated by evaluating the impact of deliberate changes on the proposed method.

\section{Degradation studies}

The guideline of the "ICH" entitled "Stability testing of new drug substances and products" states that stress testing is performed to evaluate the instinct stability attributes of the active pharmaceutical substance. Stress degradation studies on emtricitabine, tenofovir AF, and Bbictegravir ${ }^{22-27}$ were performed in the current work.

\section{Preparation of stock}

Emtricitabine (100 mg), tenofovir AF (12.5 mg), and bictegravir (25 mg) working standards were weighed and diluted to $100 \mathrm{~mL}$. The resulting stock solution was used for stability testing. All the stress conditions were applied, and the percent degradation was studied for the selected drugs bictegravir, emtricitabine, and tenofovir AF. The stress conditions include acidic, alkali, thermal, oxidative, and photolytic conditions to study the nature of drugs and their stability against the above-mentioned conditions.

\section{Statistical analysis}

The data were processed through the "EMPOWER-2". The results were calculated as mean \pm standard deviation (SD) for accuracy, and the relative SD (RSD) was calculated for precision. The coefficient of regression was also calculated for the linearity parameter.

\section{RESULTS AND DISCUSSION}

\section{Optimization of the method}

For the selection of a suitable mobile phase for simultaneous estimation of the selected drugs, various solvents such as water, ACN, TEA, and methanol varying in polarity were used in different combinations of concentrations to obtain high peak resolutions within a shorter runtime. Among all the different 
mobile phase combinations employed, the mobile phase comprising $0.2 \%$ TEA buffer and methanol in the ratio of 40:60 v/v exhibited well-defined peaks.

Different flow rates from 0.5 to $1.2 \mathrm{~mL} / \mathrm{min}$ have been studied to achieve a good peak resolution. Among all the flow rates employed, $1.2 \mathrm{~mL} / \mathrm{min}$ was selected as optimal for the study.

The column temperature was set at 25,30 , and $35^{\circ} \mathrm{C}$ for optimization, according to its effect on peak resolutions and RT of the drug samples.

During the method optimization, the selected combinations of three drugs were analyzed using different columns, the column [ODS $C_{18}(4.6 \times 250 \mathrm{~mm}, 5 \mu \mathrm{m})$ ] that exhibited good peak shape and resolution was selected for current study. The details are specified in Table 2.

Also, based on the UV-absorption spectra of the three drugs scanned over the range of $200-400 \mathrm{~nm}$, the wavelength of 260 $\mathrm{nm}$ was selected as the ideal wavelength for the study.

\section{System suitability}

According to the optimized experimental conditions, the retention times obtained for bictegravir, emtricitabine, and tenofovir AF are $5.998 \mathrm{~min}, 2.805 \mathrm{~min}$, and $4.537 \mathrm{~min}$. The optimized chromatogram with tailing factor $(<2)$, theoretical plates ( $>2000)$, resolution $(>2)$, capacitance factor $(>1)$ is shown in (Figure 4). Hence, the proposed method proved "selective" to determine the drugs (bictegravir, emtricitabine, and tenofovir AF). The system suitability results of the standard injections are tabulated in Table 3.

\section{Assay of marketed formulation}

The assay results obtained for the three drugs (bictegravir, emtricitabine, and tenofovir AF) are detailed in Table 4. No interference of the excipients was noticed in the current method; hence, the method is "specific". The typical chromatogram for assay of the commercial formulation (in-house preparation) is shown in Figure 5.

\section{Linearity}

To construct the calibration curve, different concentration ranges of bictegravir $(25-125 \mu \mathrm{g} / \mathrm{mL})$, emtricitabine (100-500 $\mu \mathrm{g} / \mathrm{mL})$, and tenofovir AF (12.5-62.5 $\mu \mathrm{g} / \mathrm{mL})$ were considered. The correlation coefficient $\left(r^{2}\right)$ values obtained were found satisfactory. The results obtained are summarized in Table 5. The calibration plots of three drugs are as shown in (Figure 6-8).

Table 2. Comparison of optimum conditions

\begin{tabular}{llll} 
S. no. & Column used & Specification & Remarks \\
\hline 1 & Hypersil & $\begin{array}{l}5.0 \times 250 \mathrm{~mm}, \\
10 \mu \mathrm{m}\end{array}$ & $\begin{array}{l}\text { Deformed peak shape } \\
\text { was observed }\end{array}$ \\
\hline 2 & Lichrosorb & $\begin{array}{l}4.6 \times 250 \mathrm{~mm}, \\
5 \mu \mathrm{m}\end{array}$ & $\begin{array}{l}\text { Low resolution } \\
\text { observed }\end{array}$ \\
\hline & & $4.6 \times 250 \mathrm{~mm}$, & $\begin{array}{l}\text { Peak shape is sharp } \\
\text { and free from Tailing } \\
\text { with high resolution }\end{array}$ \\
\hline
\end{tabular}

ODS: Octyldecylsilyl

\section{Accuracy}

Accuracy was determined at $50 \%, 100 \%$, and $150 \%$ of the test concentrations by calculating the individual recovery and mean recovery values of emtricitabine, tenofovir AF, and bictegravir. The recoveries ranged from $99.26 \%$ to $100.30 \%$ for bictegravir, $99.06 \%$ to $100.79 \%$ for emtricitabine, and $99.66 \%$ to $100.06 \%$ for tenofovir AF. The recovery values obtained were found to meet the acceptance criteria (not less than $98.0 \%$ and not more than $102.0 \%$ ). The RSD values obtained were $<2$ with respect to three drugs. The accuracy results are outlined in Table 6.

\section{Precision}

The precision for the developed method is estimated as follows:

- System precision

- Intermediate precision

- Method precision

\section{System precision}

The \% RSD of six standard injection areas were found to be less than $2 \%$ (acceptance criteria: Not more than $2 \%$ ), hence the method is "precise". The results for emtricitabine, tenofovir AF, and bictegravir are summarized in Table 7.

\section{Intermediate precision/ruggedness}

No significant effect was observed in the recoveries, the peak area responses of all the three drugs, thus indicating that the proposed and developed method is rugged.

The results are summarized for emtricitabine, tenofovir AF, and bictegravir in Table 8.

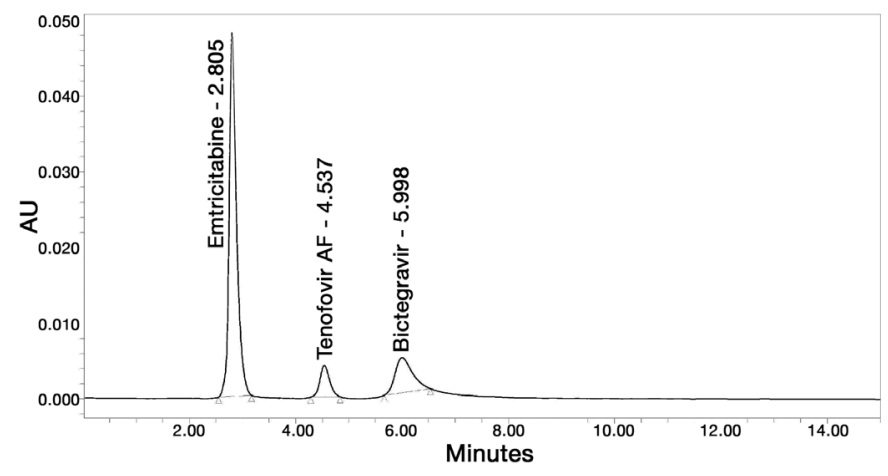

Figure 4. Optimized chromatogram showing the simultaneous elution of bictegravir, emtricitabine and tenofovir alafenamide fumarate

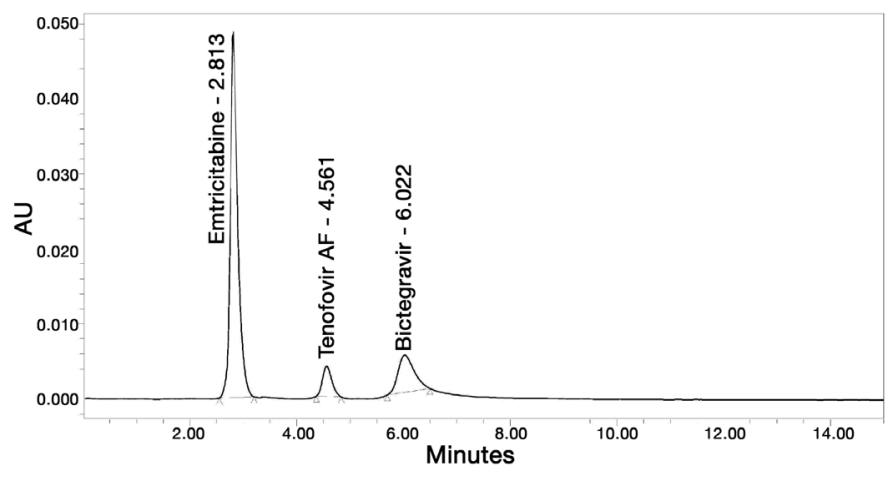

Figure 5. Assay chromatogram for marketed formulation of bictegravir, emtricitabine and tenofovir alafenamide fumarate 
Table 3. System suitability results

\begin{tabular}{llllll} 
S. no. & Parameter & Acceptance criteria & Bictegravir & Emtricitabine & Tenofovir alafenamide fumarate \\
\hline 1 & Tailing factor & Not more than 2.0 & 1.33 & 1.30 & 1.13 \\
\hline 2 & Theoretical plates & Not less than 2000 & 2214.41 & 2185.90 & 2973.76 \\
\hline 3 & $\begin{array}{l}\text { Resolution for the } \\
\text { Tenofovir AF and bictegravir }\end{array}$ & Not less than 2 & 3.14 & - & 6.05 \\
\hline 4 & Capacitance factor & Not less than 1.0 & 4.36 & 1.54 & 3.09 \\
\hline 5 & Selectivity & Not more than 2.0 & 0.5 & - & 0.7 \\
\hline
\end{tabular}

AF: Alafenamide

\section{Emtricitabine}

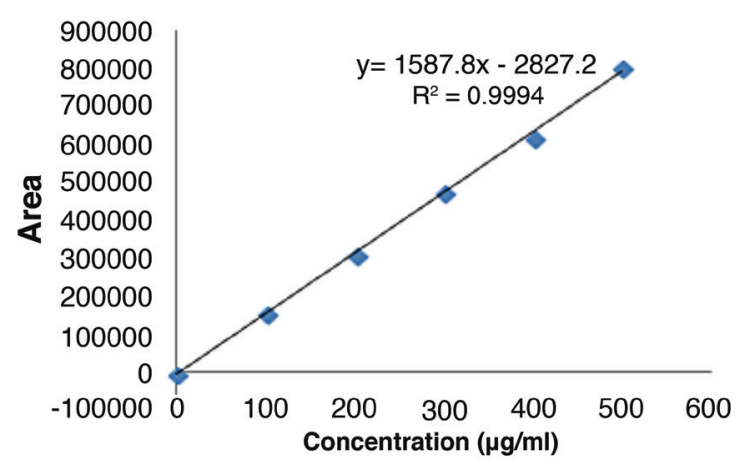

Figure 6 . Linearity graph of emtricitabine

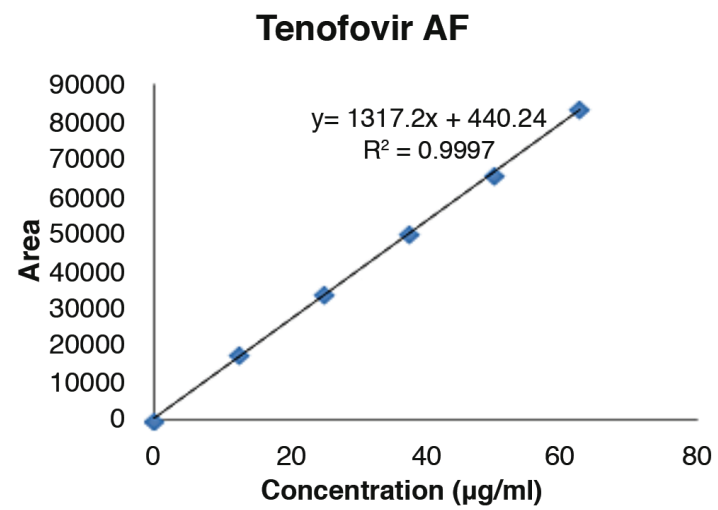

Figure 7. Linearity graph of tenofovir AF

AF: Alafenamide

Table 4. Assay results for $\%$ recoveries of marketed formulation

\begin{tabular}{|c|c|c|c|c|}
\hline S. & Parameter & $\begin{array}{l}\% \text { Recovery } \\
\text { of } \\
\text { bictegravir }\end{array}$ & $\begin{array}{l}\text { \% Recovery } \\
\text { of } \\
\text { emtricitabine }\end{array}$ & $\begin{array}{l}\% \text { Recovery } \\
\text { of tenofovir } \\
\text { AF }\end{array}$ \\
\hline
\end{tabular}

Assay

(specification:

$1 \quad$ NLT 98.0 and $\quad 99.97 \% \quad 100.48 \% \quad 99.82 \%$

NMT $102.0 \%$

$w / w)(n=3)$

$\mathrm{n}$ : Number of determinations, NLT: Not less than, NMT: Not more than, AF: Alafenamide

Table 5. Results of linearity
\begin{tabular}{lllll}
$\begin{array}{l}\text { S. } \\
\text { no. }\end{array}$ & Parameters & Bictegravir & Emtricitabine & $\begin{array}{l}\text { Tenofovir } \\
\text { AF }\end{array}$ \\
\hline 1 & $\begin{array}{l}\text { Linearity range } \\
(\mu \mathrm{g} / \mathrm{mL})\end{array}$ & $25-125$ & $100-500$ & $12.5-62.5$ \\
\hline 2 & $\begin{array}{l}\text { Correlation } \\
\text { coefficient }\left(r^{2}\right)\end{array}$ & 0.999 & 0.999 & 0.999 \\
\hline 3 & Slope & 1287.3 & 1587.8 & 1317.2 \\
\hline 4 & Intercept & 1224.6 & 2827.2 & 440.24 \\
\hline AF: Alafenamide & & &
\end{tabular}

\section{Table 6. Results of accuracy}

\begin{tabular}{lllll}
$\begin{array}{l}\text { S. } \\
\text { no. }\end{array}$ & $\begin{array}{l}\text { Concentration } \\
\text { (at specification } \\
\text { level) }(n=3)\end{array}$ & $\begin{array}{l}\text { \% Recovery } \\
\text { of } \\
\text { bictegravir }\end{array}$ & $\begin{array}{l}\text { \% Recovery } \\
\text { of } \\
\text { emtricitabine }\end{array}$ & $\begin{array}{l}\text { \% Recovery } \\
\text { of tenofovir } \\
\text { AF }\end{array}$ \\
\hline 1 & $50 \%$ & 99.26 & 100.44 & 100.06 \\
\hline 2 & $100 \%$ & 100.30 & 100.79 & 99.66 \\
\hline 3 & $150 \%$ & 100.01 & 99.06 & 99.75 \\
\hline
\end{tabular}

$\mathrm{n}$ : Number of determinations, AF: Alafenamide

\section{Method precision}

To evaluate the method precision, the \% assay was calculated from six individual samples solutions analyzed on same day. The \% RSD obtained with respect to the results of the method precision met the acceptance criteria (not more than $2 \%$ ), and the details of peak areas and \% RSD values are summarized in Table 9.

\section{Robustness}

Robustness is defined as how the method can resist (less impact) small and deliberate changes in analytical procedure parameters such as the flow rate $( \pm 10 \%)$ and the organic phase composition $( \pm 10 \%)$. Minor changes did not affect the peak area responses of the method significantly; hence, the proposed method is robust.

The flow rate $(1.08 \mathrm{~mL} / \mathrm{min}$ and $1.32 \mathrm{~mL} / \mathrm{min})$ and organic phase composition (lesser to more organic) were altered, and there was no significant variation in the results obtained when deliberate changes were made to the developed method. The results obtained for the parameter robustness are summarized in Table 10-15. 


\section{$D L$ and $Q L$}

$\mathrm{DL}$ and $\mathrm{QL}$ values were estimated using the formulas:

$\mathrm{DL}=3.3 \times(\sigma / \mathrm{S})$

$\mathrm{QL}=10 \times(\sigma / \mathrm{S})$

where;

$\sigma=$ standard deviation;

$\mathrm{S}=$ slope.

The $\mathrm{DL}$ values for bictegravir, emtricitabine, and tenofovir AF obtained were $2.7,1.05$, and $1.35 \mu \mathrm{g} / \mathrm{mL}$, with signal to noise ratio of 3:1, and the QL values for bictegravir, emtricitabine, and tenofovir AF obtained were $8.78,3.30$, and $4.61 \mu \mathrm{g} / \mathrm{mL}$, with a signal to noise ratio of 10:1, which indicates that the "sensitivity" of the method is adequate. The results are summarized in Table 16.

\section{Hydrolytic degradation under acidic conditions}

To $3.0 \mathrm{~mL}$ of the stock solution, $3 \mathrm{~mL}$ of $1 \mathrm{~N} \mathrm{HCl}$ was added, diluted to $10 \mathrm{~mL}$, and incubated at $60^{\circ} \mathrm{C}$ for 6 hours. The resulting solution was neutralized with $1 \mathrm{~N} \mathrm{NaOH}$ and adjusted to the mark with the diluent. There was no remarkable acid degradation with respect to the subject drugs, and the chromatogram is shown in Figure 9.

\section{Bictegravir}

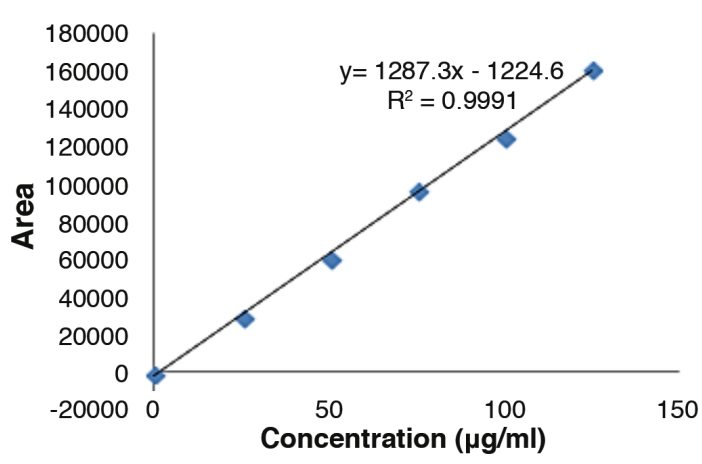

Figure 8. Linearity graph of bictegravir

Table 7. Results of system precision

\begin{tabular}{llll}
\multirow{2}{*}{ Injection } & \multicolumn{3}{c}{ Peak areas } \\
\cline { 2 - 4 } & Emtricitabine & Tenofovir AF & Bictegravir \\
\hline Injection-1 & $4,74.652$ & 50.304 & 97.274 \\
\hline Injection-2 & $4,70.806$ & 50.532 & 96.658 \\
\hline Injection-3 & $4,79.900$ & 50.680 & 97.574 \\
\hline Injection-4 & $4,73.621$ & 50.727 & 97.021 \\
\hline Injection-5 & $4,75.167$ & 50.255 & 98.232 \\
\hline Injection-6 & $4,76,538$ & 50.235 & 97,987 \\
\hline Average & $4,75,114.0$ & $50,455.5$ & $97,457.7$ \\
\hline Standard deviation & $3,031.1$ & 219.9 & 592.8 \\
\hline \% RSD ( $n=6)$ & 0.6 & 0.4 & 0.6
\end{tabular}

$\mathrm{n}$ : Number of determinations, RSD: Relative standard deviation, AF: Alafenamide

\section{Hydrolytic degradation under alkaline conditions}

To $3.0 \mathrm{~mL}$ of the stock solution, $1 \mathrm{~N} \mathrm{NaOH}(3 \mathrm{~mL}$ ) was added, diluted to $10 \mathrm{~mL}$, and incubated at $60^{\circ} \mathrm{C}$ for 6 hours. Later, the solution was neutralized with $1 \mathrm{~N} \mathrm{HCl}$. There was no significant degradation with respect to the three drugs, and the chromatogram obtained for alkali degradation is shown in Figure 10.

\section{Thermal-induced degradation}

The subject samples were placed separately in Petri dishes and remained in an oven at $110^{\circ} \mathrm{C}$ for a period of 24 hours. There was a minimal effect of thermal degradation

Table 8. Results of intermediate precision/ruggedness

\begin{tabular}{llll}
\multirow{2}{*}{ Injection } & \multicolumn{3}{c}{ Peak areas } \\
\cline { 2 - 4 } & Emtricitabine & Tenofovir AF & Bictegravir \\
\hline Injection-1 & $4,77.752$ & 49.821 & 97.234 \\
\hline Injection-2 & $4,74.159$ & 50.388 & 96.991 \\
\hline Injection-3 & $4,69.272$ & 50.289 & 95.433 \\
\hline Injection-4 & $4,69,317$ & 50.176 & 96.414 \\
\hline Injection-5 & $4,77.171$ & 50.337 & 97.491 \\
\hline Injection-6 & $4,73.102$ & 50.073 & 97.166 \\
\hline Average & $4,73,462.2$ & 50.180 .7 & $96,788.2$ \\
\hline Standard deviation & $3,674.6$ & 209.8 & 755.4 \\
\hline $\begin{array}{l}\text { \% RSD (n=6) } \\
\text { n: Number of determinations, RSD: }\end{array}$ & Relative standard & deviation, AF: \\
Alafenamide & 0.8 & &
\end{tabular}

\section{Table 9. Results for method precision}

\begin{tabular}{lllll} 
& \multirow{2}{*}{$\begin{array}{l}\text { Sample } \\
\text { weight }\end{array}$} & \multicolumn{3}{c}{ Peak areas } \\
\cline { 3 - 5 }$(\mathbf{m g})$ & Emtricitabine & $\begin{array}{l}\text { Tenofovir } \\
\text { AF }\end{array}$ & Bictegravir \\
\hline $\begin{array}{l}\text { Method } \\
\text { precision-1 }\end{array}$ & 174.2 & $4,75.652$ & 50.166 & 97.455 \\
\hline $\begin{array}{l}\text { Method } \\
\text { precision-2 }\end{array}$ & 174.5 & $4,76.888$ & 50.425 & 97.563 \\
\hline $\begin{array}{l}\text { Method } \\
\text { precision-3 }\end{array}$ & 174.1 & $4,75.988$ & 50.253 & 97.234 \\
\hline $\begin{array}{l}\text { Method } \\
\text { precision-4 }\end{array}$ & 174.3 & $4,75.377$ & 50.497 & 97.331 \\
\hline $\begin{array}{l}\text { Method } \\
\text { precision-5 }\end{array}$ & 174.2 & $4,76.765$ & 50.556 & 97.548 \\
\hline $\begin{array}{l}\text { Method } \\
\text { precision-6 }\end{array}$ & 174.3 & $4,76.653$ & 50.335 & 97.397 \\
\hline Average & - & $4,76,220.5$ & $50,372.0$ & 97.421 .3 \\
\hline $\begin{array}{l}\text { Standard } \\
\text { deviation }\end{array}$ & - & 635.3 & 148.5 & 127.4 \\
\hline \% RSD (n=6) & - & 0.1 & 0.3 & 0.1 \\
\hline
\end{tabular}

$\mathrm{n}$ : Number of determinations, RSD: Relative standard deviation, AF: Alafenamide 
with respect to the drug emtricitabine and no significant effect with respect to bictegravir and tenofovir AF. The chromatogram obtained for thermal degradation is shown in (Figure 11).

\section{Oxidative degradation}

To the above stock solution, $3 \mathrm{~mL}$ of $3 \%(\mathrm{w} / \mathrm{v}$ ) hydrogen peroxide $(1 \mathrm{~mL}$ ) was added in a $10 \mathrm{~mL}$, and the flask was retained at ambient temperature for 12 minutes. There was a minimal

Table 10. System suitability results for emtricitabine at a flow rate variation of $\pm 10 \%$

\begin{tabular}{llll} 
& \multirow{2}{*}{ S. no. } & Flow rate & \multicolumn{2}{c}{ System suitability results } \\
\cline { 3 - 4 } & $(\mathrm{mL} / \mathrm{min})$ & USP tailing $\left(\mathrm{T}_{\mathrm{f}}\right)$ & USP plate count $(\mathrm{N})$ \\
\hline 1 & 1.08 & 1.37 & 2371.09 \\
\hline 2 & 1.2 & 1.30 & 2185.90 \\
\hline 3 & 1.32 & 1.31 & 2231.87 \\
\hline
\end{tabular}

$T_{f}$ : Tailing factor

Table 11. System suitability results for tenofovir AF at a flow rate variation of $\pm 10 \%$

\begin{tabular}{lllll} 
& \multirow{2}{*}{$\begin{array}{l}\text { S. } \\
\text { no. }\end{array}$} & Flow rate & \multicolumn{3}{c}{ System suitability results } \\
\cline { 3 - 5 } & & USP resolution & $\begin{array}{l}\text { USP tailing } \\
(\mathrm{m})\end{array}$ & $\begin{array}{l}\text { USP plate } \\
\text { count }(\mathrm{N})\end{array}$ \\
\hline 1 & 1.08 & 6.32 & 1.25 & 3223.82 \\
\hline 2 & 1.2 & 6.05 & 1.13 & 2973.76 \\
\hline 3 & 1.32 & 6.07 & 1.06 & 2863.39 \\
\hline
\end{tabular}

AF: Alafenamide, $T_{f}$ : Tailing factor

Table 12. System suitability results for bictegravir at a flow rate variation of $\pm 10 \%$

\begin{tabular}{lllll} 
& & \multicolumn{3}{c}{ System suitability results } \\
\cline { 3 - 5 } no. & $\begin{array}{l}\text { Flow rate } \\
(\mathrm{mL} / \mathrm{min})\end{array}$ & $\begin{array}{l}\text { USP resolution } \\
(\mathrm{R})\end{array}$ & $\begin{array}{l}\text { USP tailing } \\
\left(\mathrm{T}_{\mathrm{f}}\right)\end{array}$ & $\begin{array}{l}\text { USP plate count } \\
(\mathrm{N})\end{array}$ \\
\hline 1 & 1.08 & 3.28 & 1.31 & 2143.54 \\
\hline 2 & 1.2 & 3.14 & 1.33 & 2214.41 \\
\hline 3 & 1.32 & 3.20 & 1.40 & 2183.37 \\
\hline
\end{tabular}

$\mathrm{T}_{\mathrm{f}}$ : Tailing factor

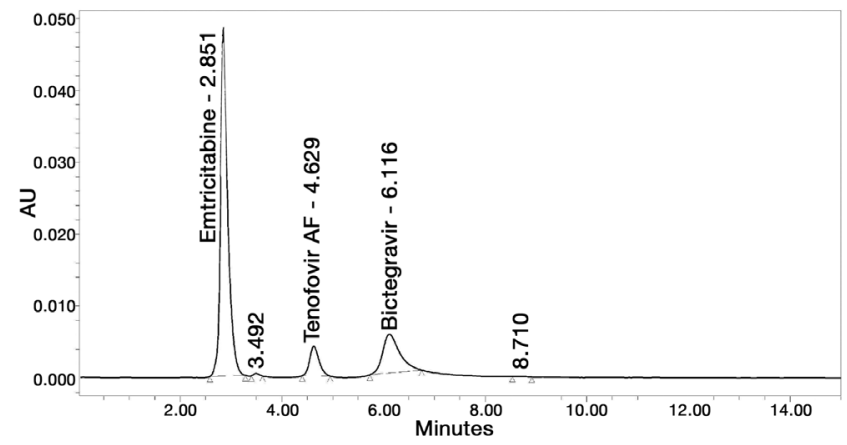

Figure 9. Acidic degradation chromatogram of bictegravir, emtricitabine and tenofovir alafenamide fumarate

AF: Alafenamide effect of thermal degradation on bictegravir and tenofovir AF and no significant effect noticed with respect to emtricitabine. The chromatogram obtained for the oxidative degradation is shown in (Figure 12).

\section{Photo degradation}

The sample solution was exposed to external sunlight. No significant degradation was noticed with respect to the subject drugs, and the chromatogram obtained for the photolytic degradation is shown in (Figure 13).

A stability study was conducted for the drugs emtricitabine, tenofovir AF, and bictegravir under the respective stress conditions. The peak areas obtained, the \% assay calculated,

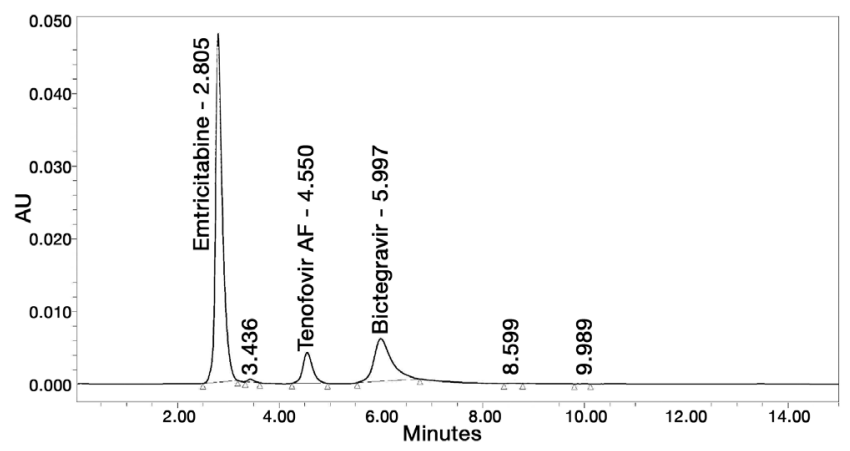

Figure 10. Alkali degradation chromatogram of bictegravir, emtricitabine and tenofovir alafenamide fumarate

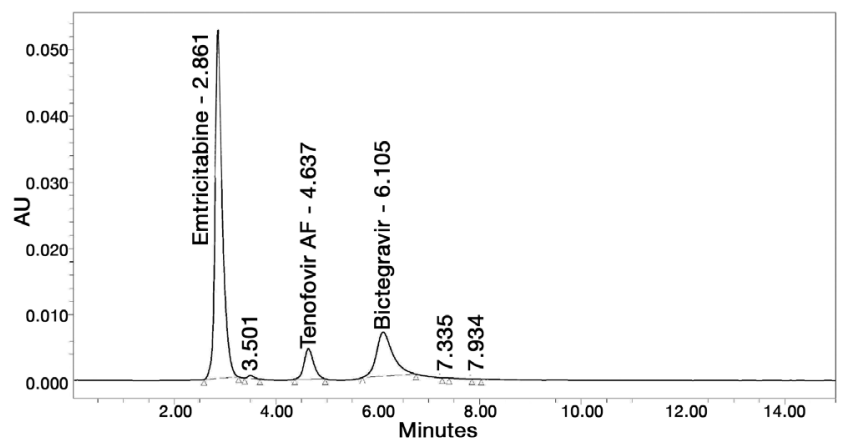

Figure 11. Thermal degradation chromatogram of bictegravir, emtricitabine and tenofovir alafenamide fumarate

AF: Alafenamide

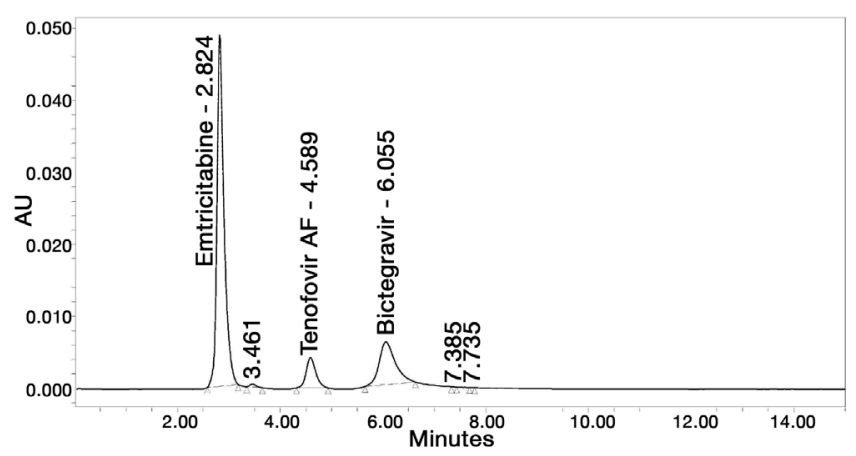

Figure 12. Oxidative degradation chromatogram of bictegravir, emtricitabine and tenofovir alafenamide fumarate

AF: Alafenamide 
Table 13. System suitability results for emtricitabine at variation of the organic phase $\pm 10 \%$

\begin{tabular}{llll}
\multirow{2}{*}{ S. no. } & \multirow{2}{*}{$\begin{array}{l}\text { Organic } \\
\text { phase ratio }\end{array}$} & \multicolumn{2}{l}{ System suitability results } \\
\cline { 3 - 4 } & USP tailing $\left(\mathrm{T}_{\mathrm{f}}\right)$ & USP plate count $(\mathrm{N})$ \\
\hline 1 & Less organic & 1.38 & 2254.66 \\
\hline 2 & Actual & 1.30 & 2185.90 \\
\hline 3 & More organic & 1.32 & 2263.23 \\
\hline
\end{tabular}

$T_{f}$ : Tailing factor

Table 14. System suitability results for tenofovir AF at variation of the organic phase $\pm 10 \%$

\begin{tabular}{lllll}
\multirow{2}{*}{$\begin{array}{l}\text { S. } \\
\text { no. }\end{array}$} & Organic phase & \multicolumn{3}{l}{ System suitability results } \\
\cline { 3 - 5 } & ratio & $\begin{array}{l}\text { USP resolution } \\
(\mathrm{R})\end{array}$ & $\begin{array}{l}\text { USP } \\
\text { tailing }\left(\mathrm{T}_{\mathrm{f}}\right)\end{array}$ & $\begin{array}{l}\text { USP plate } \\
\text { count }(\mathrm{N})\end{array}$ \\
\hline 1 & Less organic & 9.22 & 1.05 & 3228.79 \\
\hline 2 & Actual & 6.05 & 1.13 & 2973.76 \\
\hline 3 & More organic & 4.09 & 1.26 & 2672.79 \\
\hline
\end{tabular}

$\mathrm{T}_{\mathrm{f}}$ : Tailing factor, AF: Alafenamide
Table 15. System suitability results for bictegravir at variation of the organic phase $\pm 10 \%$

\begin{tabular}{lllll}
\multirow{2}{n}{$\begin{array}{l}\text { S. } \\
\text { no. }\end{array}$} & $\begin{array}{l}\text { Organic phase } \\
\text { ratio }\end{array}$ & \multicolumn{3}{l}{ System suitability results } \\
\cline { 3 - 5 } & $\begin{array}{l}\text { USP } \\
\text { resolution }\end{array}$ & $\begin{array}{l}\text { USP } \\
\text { tailing }\end{array}$ & $\begin{array}{l}\text { USP plate } \\
\text { count }\end{array}$ \\
\hline 1 & Less organic & 4.65 & 1.10 & 2113.59 \\
\hline 2 & Actual & 3.14 & 1.33 & 2214.41 \\
\hline 3 & More organic & 2.16 & 1.49 & 2195.87 \\
\hline
\end{tabular}

Table 16. Results of detection limit and quantification limit

\begin{tabular}{llllll}
$\begin{array}{l}\text { S. } \\
\text { no. }\end{array}$ & Sample & $\begin{array}{l}\mathrm{DL} \\
(\mu \mathrm{g} / \mathrm{mL})\end{array}$ & $\begin{array}{l}\mathrm{QL} \\
(\mu \mathrm{g} / \mathrm{mL})\end{array}$ & $\begin{array}{l}\mathrm{DL} \mathrm{S} / \mathrm{N} \\
\text { ratio }\end{array}$ & $\begin{array}{l}\mathrm{QL} \mathrm{S} / \mathrm{N} \\
\text { ratio }\end{array}$ \\
\hline 1 & Bictegravir & 2.7 & 8.78 & 3.02 & 10 \\
\hline 2 & Emtricitabine & 1.05 & 3.30 & 3 & 9.98 \\
\hline 3 & Tenofovir AF & 1.35 & 4.61 & 2.96 & 10.02 \\
\hline
\end{tabular}

DL: Detection limit, QL: Quantification limit, S: Selectivity

Table 17. Results of \% degradation by stability testing

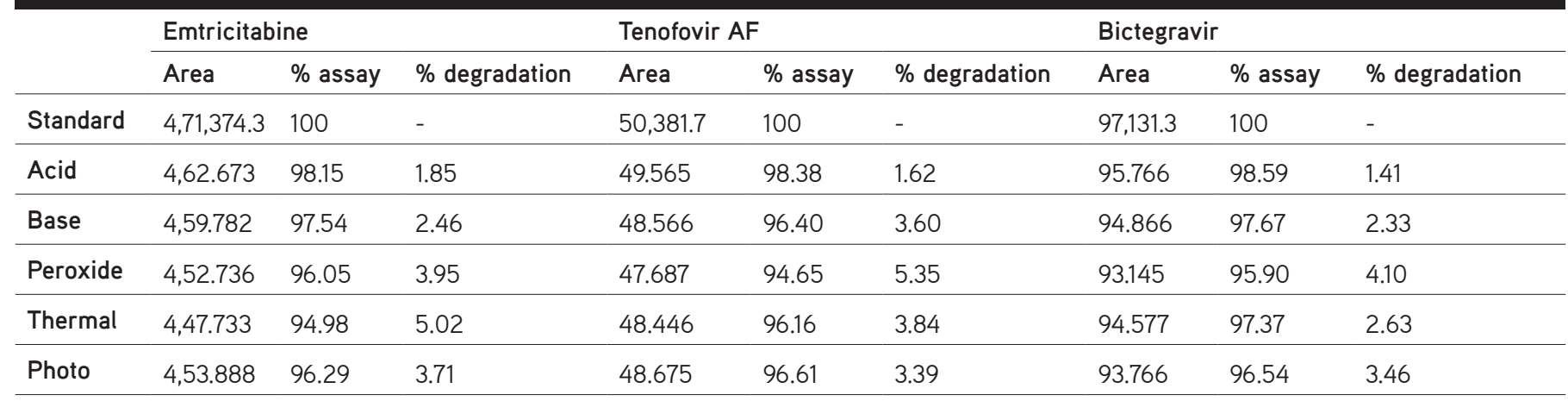

AF: Alafenamide

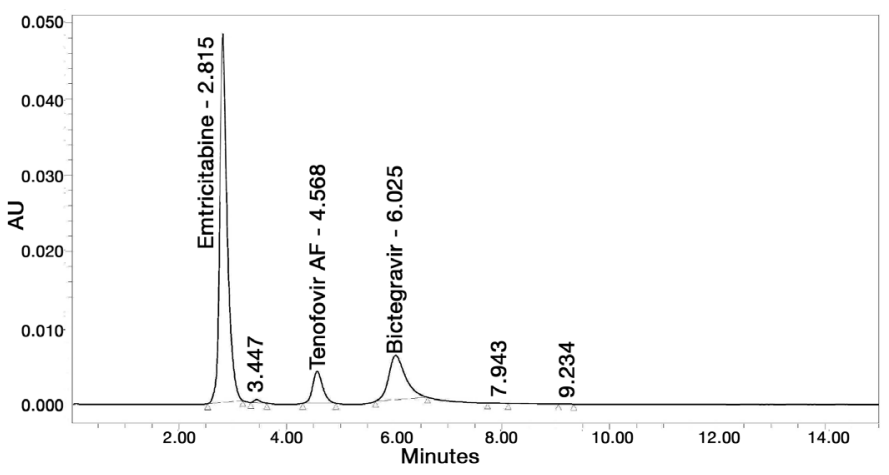

Figure 13. Photolytic degradation chromatogram of bictegravir, emtricitabine \& tenofovir alafenamide fumarate AF: Alafenamide

and the \% degradation observed are summarized and detailed in Table 17. From the above data, it is evident that the drug "emtricitabine" is sensitive to thermal conditions, "tenofovir AF" and "bictegravir" are sensitive to oxidative conditions.

\section{CONCLUSION}

The newly developed method affirms good resolution between the three drugs bictegravir, emtricitabine, and tenofovir AF. The current method, method validation, and stability studies were found to be in line with the $\mathrm{ICH}$ guidelines and with official methods. The method requires no core extraction techniques; moreover, economical solvents are employed for the analysis, and good resolution is attained. No interference from any pharmaceutical dosage form or any remarkable impurities of degraded substance(s) was observed. Since the subject drugs of interest were analyzed by employing less expensive solvents and obtaining high resolution and shorter retention times with respect to the current method, the new proposed method is recommended for routine quality control analysis to provide simple, reliable, economical, and reproducible quantitative analysis for simultaneous estimation of the selected antiretroviral fixed-dose regimen (bictegravir, emtricitabine, and tenofovir AF). 


\section{ACKNOWLEDGMENTS}

Authors extend intense gratitude to M/S Pharma Train Labs, Hyderabad for providing the required research facilities and to Hetero Labs, Hyderabad for providing gift samples of bictegravir, emtricitabine and tenofovir AF.

Conflict of interest: No conflict of interest was declared by the authors. The authors are solely responsible for the content and writing of this paper.

\section{REFERENCES}

1. Atkinson MJ, Petrozzino JJ. An evidence-based review of treatmentrelated determinants of patients' nonadherence to HIV medications. AIDS Patient Care STDs. 2009;23:903-914.

2. Hester EK. HIV medications: an update and review of metabolic complications. Nutr Clin Pract. 2012;27:51-64.

3. Margolis AM, Heverling $H$, Pham PA, Stolbach A. A review of the toxicity of HIV medications. J Med Toxicol. 2014;10:26-39.

4. Tsiang M, Jones GS, Goldsmith J, Mulato A, Hansen D, Kan E, Tsai L, Bam RA, Stepan G, Stray KM, Niedziela-Majka A. Antiviral activity of bictegravir (GS-9883), a novel potent HIV-1 integrase strand transfer inhibitor with an improved resistance profile. Antimicrobial Agents Chemother. 2016;60:7086-7097.

5. Hassounah SA, Alikhani A, Oliveira M, Bharaj S, Ibanescu RI, Osman $\mathrm{N}, \mathrm{Xu} H \mathrm{HT}$, Brenner BG, Mesplède T, Wainberg MA. Antiviral activity of bictegravir and cabotegravir against integrase inhibitor-resistant SIVmac239 and HIV-1. Antimicrobial Agents Chemother. 2017;61:e0169517. doi: 10.1128/AAC.01695-17.

6. Neogi U, Singh K, Aralaguppe SG, Rogers LC, T NJENDA D, Sarafianos $S G$, Hejdeman B, Sönnerborg A. Ex vivo antiretroviral potency of newer integrase strand transfer inhibitors cabotegravir and bictegravir in HIV-1 non-B subtypes. AIDS (London, England). 2018;32:469.

7. Pharmaceutical Benefits Scheme. Summary of Changes (March 2019). Canberra: Department of Health, 2019. Last Accessed Date: 16.04.2019. Available from: https://www.pbs.gov.au/info/publication/schedule/ archive

8. Pharmaceutical Benefits Scheme. PBS Schedule: Bictegravir + emtricitabine + tenofovir alafenamide. Canberra: Department of Health, 2019. Last Accessed Date: 16.04.2019. Available from: https://www.pbs. gov.au/medicine/item/11649D

9. Pharmaceutical Benefits Scheme. Public Summary Documents: Bictegravir + emtricitabine + tenofovir alafenamide fixed dose combination (March 2018). Canberra: Department of Health, 2018. Last Accessed Date: 20.02.2019.Available from: https://www.pbs.gov.au/ pbs/industry/listing/elements/pbac-meetings/psd/2018-03/bictegraviremtricitabine--psd-march-2018

10. Gilead Sciences Pty Ltd. Bictegravir + emtricitabine + tenofovir alafenamide (Biktarvy) product information. Melbourne: Gilead Sciences, 2018. Last Accessed Date: 20.02.2019. Available from: https://www.tga. gov.au/sites/default/files/auspar-bictegravir-emtricitabine-tenofoviralafenamide-190801-pi.pdf

11. Stellbrink HJ, Lazzarin A, Woolley I, Llibre JM. The potential role of bictegravir/emtricitabine/tenofovir alafenamide (BIC/FTC/TAF) singletablet regimen in the expanding spectrum of fixed-dose combination therapy for HIV. HIV medicine. 2020 Mar;21:3-16.
12. Jules Levin, Kirsten White, Tomas Cihlar and Michael D. Miller, Potent Activity of Bictegravir (BIC; GS-9883), a Novel Unboosted HIV-1 Integrase Strand Transfer Inhibitor (INSTI), Against Patient Isolates with INSTI-Resistance ASM/ICAAC 2016 June 16-20 Boston, MA.

13. Kokkirala TK, Suryakala D. RP-HPLC method development and validation for the estimation of Emtricitabine, Bictegravir and Tenofovir alafenamide in bulk and pharmaceutical dosage form. J Taibah Univ Sci. 2019;13:11371146.

14. Sneha M, Valli Kumari RV Stability indicating RP-HPLC method for simultaneous estimation of emtricitabine, bictegravir and tenofovir alafenamide in bulk and formulation. Int J Pharm Anal Res. 2019;8:281292.

15. Sattar MA, Achanta S. Analytical method development and validation for the determination of emtricitabine and tenofovir disoproxil fumarate using reverse phase hplc method in bulk and tablet dosage form. J Pharm Sci Res. 2018;10:1207-1212.

16. Meenaksh R, Shyam Sunder R. Method development and validation by RP-HPLC for simultaneous estimation of emtricitabine, bictegravir, tenofovir alafenamide in fixed dosag. Indo Am J Pharm Sci. 2018;5:71237131.

17. Dighe NS, Shinde GS, Magar SD, Deodhe AV. Development and validation of RP-HPLC method for simultaneous estimation of emtricitabine and tenofovir disoproxil fumarate in bulk and tablet dosage form. J Drug Deliv Ther. 2019;9:693-698.

18. Kalamkar CS, Bhawar SB. Development and validation of RP-HPLC method for the simultaneous estimation of tenofovir alafenamide fumarate and emtricitabine in bulk and tablet dosage form. J Drug Deliv Ther. 2019;9:243-247.

19. Liao C, Marchand C, Burke Jr TR, Pommier Y, Nicklaus MC. Authentic HIV-1 integrase inhibitors. Future Med Chem. 2010;2:1107-1122.

20. Carr GP, Wahlich JC. A practical approach to method validation in pharmaceutical analysis. J Pharm Biomed Anal. 1990;8:613-618.

21. Asian Rockville MD. The United States Pharmacopeia: USP 24 the National Formulary: NF 19: by authority of the United States Pharmacopoeial Convention, Inc., meeting at Washington, D.C., March 9-12, 1995 ; prepared by the Committee of Revision and published by the Board of Trustees. Washington: United States Pharmacopoeia Convention Inc; 2000.

22. ICH. "International Conference on Harmonization of Technical Requirements for Registration of Pharmaceuticals for Human Use. Validation of Analytical Procedures: Text and Methodology". 2005.

23. Procedures, Analytical. "Method Validation. US Food and Drug Administration." Center for Drugs and Biologics, Department of Health and Human Services 2000.

24. Blessy MR, Patel RD, Prajapati PN, Agrawal YK. Development of forced degradation and stability indicating studies of drugs-a review. J Pharm Anal. 2014;4:159-165.

25. Venkataraman S, Manasa M. Forced degradation studies: Regulatory guidance, characterization of drugs, and their degradation products-a review. Drug Invention Today. 2018;10:137-146.

26. Aggarwal NN, Bhat KI, Jacob JT. Stability indicating assay method development and validation for tenofovir alafenamide fumarate by RPHPLC. Pharm Anal Acta. 2018;9:601.

27. Vetapalem R, Yejella RP, Atmakuri LR. Development and validation of a stability indicating RP-HPLC method for simultaneous estimation of teneligliptin and metformin. Turk J Pharm Sci. 2020;17:141-147. 